\title{
Realimentação auditiva atrasada e tratamento de gagueira: evidências a serem consideradas $* * * *$
}

\author{
Using delayed auditory feedback in the treatment of stuttering: \\ evidence to consider
}

\author{
John Van Borsel* \\ Sarah Sierens** \\ Mônica Medeiros de Britto Pereira***
}

\section{* Neurolingüista. Professor Titular do Ghent University Hospital - Ghent - Bélgica. Endereço para correspondência: UZ Gent 2P1 - De Pintelaan 185 - B-9000 Gent - Belgium - ID 590-1770853-47 \\ (John.Vanborsel@Ugent.be). \\ ** Graduanda em Fonoaudiologia pela Ghent University Hospital - Ghent - Bélgica. \\ *** Fonoaudióloga. Doutora em Lingüística pela Universidade Federal de Minas Gerais. Professor adjunto da Universidade Veiga de Almeida.}

****Trabalho Realizado na Ghent University / Universidade Veiga de Almeida.

Artigo de Revisão de Literatura

Artigo Submetido a Avaliação por Pares

Conflito de Interesse: não

Recebido em 19.09.2006.

Revisado em 15.05.2007; 05.07.2007.

Aceito para Publicação em 18.07.2007.

\begin{abstract}
Background: there is some indication that the use of delayed auditory feedback (DAF) is a potentially helpful technique in the treatment of stuttering. Several devices for DAF are also commercially. However, not all individuals who stutter experience a positive effect on speech fluency when speaking under DAF. And those who do show a positive effect, may differ considerably as to the degree and the conditions in which the effect is seen. Therefore, the decision whether or not to attempt the use of DAF in an given client is usually not straightforward. Aim: starting from a literature review, the present paper discusses and illustrates factors to take into account when considering the use of RAA in an individual client. Four types of factors are distinguished: factors inherent to the client such as gender, age, stuttering severity, dysfluency pattern, origin of stuttering, and biological subtype; factors outside the client including delay time, intensity, manner of delivery, speech mode, and speech situation; possible side-effects like a reduction in speech rate, an increase of speaking fundamental frequency and vocal intensity, lengthening of vowels, and a possible effect on speech naturalness; others namely cosmetics, finances, and the long-term effect. Conclusion: the review shows that most likely multiple factors play a role, but with the currently available data it is very hard to predict whether a given individual will or will not benefit from the use of DAF. Overall, the evidence for the influence of the different factors is still meager. Moreover, some studies present data of a quality that can hardly be considered "evidence".
\end{abstract}

Key Words: Stuttering; Treatment; Delayed Auditory Feedback.

\section{Resumo}

Tema: a realimentação auditiva atrasada (RAA) é ao que parece, uma técnica que tem sido utilizada no tratamento da gagueira com bons resultados. Muitos aparelhos de RAA são comercializados. No entanto, nem todas as pessoas que gaguejam experimentam melhora na fluência da fala ao utilizar a RAA e quando os efeitos são positivos observam-se diferenças consideráveis em relação ao grau e às condições em que a melhora na fala ocorreu. Neste sentido, a decisão de utilizar ou não a RAA no tratamento de um cliente nem sempre é óbvia. Objetivo: o presente artigo se propõe a discutir e ilustrar fatores a serem considerados, no que se refere à utilização da RAA em terapia individual, com base em uma revisão de literatura. Quatro tipos de fatores são apresentados: fatores inerentes ao cliente, tais como sexo, idade, severidade de gagueira, tipologia da disfluência, origem da gagueira e tipo biológico; fatores externos ao cliente, como o tempo de retorno da informação auditiva, intensidade, modo de apresentação, modalidade e situação de fala; possíveis efeitos colaterais como redução da velocidade de fala, aumento da freqüência fundamental e da intensidade vocal, prolongamento de vogais e um possível efeito na naturalidade fala; outros fatores como questões estéticas, questões financeiras e duração do efeito na fala. Conclusão: a revisão aponta a influência de fatores múltiplos, mas com os dados existentes é difícil predizer se o indivíduo será ou não beneficiado pelo uso da RAA. Em suma, além das evidências em relação à influência de diferentes fatores serem ainda pobres, alguns estudos apresentam dados de pouca qualidade que não podem ser considerados "evidência".

Palavras-Chave: Gagueira; Tratamento; Realimentação Auditiva Atrasada.

Referenciar este material como:

BORSEL, J. V.; SIERENS, S.; PEREIRA, M. M. B. Using delayed auditory feedback in the treatment of stuttering: evidence to consider (original title: Realimentação 13 auditiva atrasada e tratamento de gagueira: evidências a serem consideradas). Pró-Fono Revista de Atualização Científica, Barueri (SP), v. 19, n. 3, p. 323-332, jul.set. 2007. 


\section{Introduction}

Stuttering is complex speech disorder that is not so easy to define (Schiefer, 2005). According to the World Health Organization (1977) stuttering is a disorder in the rhythm of speech in which the individual knows precisely what he or she wishes to say, but at the time is unable to say it because of an involuntary repetition, prolongation, or cessation of a sound. The prevalence of stuttering in general is estimated at about $1 \%$ with a male to female ratio of 3 to 1. (Bloodstein, 1995). A higher prevalence is usually reported in children. Andrade (1997), for instance, found a prevalence of about $2,9 \%$ in 2.980 children from 1 to 11:11 years of age of a neighborhood of the city of São Paulo (Butantã community).

Therapy for stuttering usually falls into one of two groups: fluency shaping approaches or stuttering modification approaches. Stuttering modification therapies are based on the reduction of the avoidance behaviors, fears and negative attitudes of the stutterers (Andrade, 2003). The concepts and feelings associated with stuttering can be very strong (Andrade et al, 2004) and vary among different countries and cultures (St Louis et al, 2005). Examples of stuttering modification therapies are the methods of Van Riper (1973) and Gregory (1986). Fluency shaping programs, on the other hand, aim at enhancing fluency by the stimulation of areas that will help the stutterer to monitor his speech. An example of this approach is the PFPF (Programa Fonoaudiológico de Promoção de Fluência) developed by Andrade (2003). Fluency shaping therapy sometimes make use of techniques such as surface electromyography (Sassi,, 2003, Andrade e Sassi, 2003, Sassi and Andrade, 2004) and also delayed auditory feedback. In the latter technique a speaker's verbal output is fed back in to his ears after a short delay.

In 1950 B.S. Lee first reported on the deleterious effects of delayed auditory feedback (DAF) on the speech of normally fluent speakers. He called the effect "startling", causing the person to stutter, to slow down while raising his voice in pitch or volume, or to stop completely. Some of his subjects tested developed "a quavering slow speech of the type associated with cerebral palsy" and revealed "tension by reddening the face" (p. 640). Soon after studies appeared showing that in individuals who stutter, by contrast, DAF may improve speech fluency (Nessel, 1958; Lotzmann, 1961; Chase et al., 1961a; Bohr, 1963; Zerneri, 1966; Soderberg, 1969). Today there is some evidence that the use of DAF is a potentially helpful technique in the treatment of stuttering (Kalinowski et al., 1993, 1996; Stuart et al., 1997; Stuart and Kalinowski , 2004; Sparks et al., 2002; Macleod et al., 1995; Van Borsel et al., 2003). Several devices for DAF are also commercially available ranging from large-sized desk models over body-worn battery-powered devices to (almost) invisible prosthetic DAF devices.

It should be recognized too, however, that not all individuals who stutter experience a positive effect on speech fluency when speaking under DAF. And those who do show a positive effect, may differ considerably as to the degree and the conditions in which the effect is seen (Bloodstein, 1995; Ward, 2006). The outcome in a given client probably is a function of multiple factors and as such the decision whether or not to attempt the use of DAF is usually not straightforward. Starting from a literature review, the present paper has as an objective to discuss and illustrate factors to take into account when considering the use of DAF in an individual client. Four types of factors can be distinguished: factors inherent to the client, factors outside the client, possible side-effects, and others.

\section{Factors inherent to the client}

Among the factors inherent to the client with a possible influence on the effect of DAF are gender, age, stuttering severity, dysfluency pattern, origin of stuttering, and biological subtype.

\section{Gender}

It has been shown that in non-stutterers males are more susceptible to DAF than females (Bachrach, 1964; Mahaffey and Stromstra, 1965; Timmons, 1971; Fukawa et al. , 1988). In people who stutter there appears to be no difference in the effect of DAF in male versus female stutterers (Fukawa et al., 1988). Grosser et al. (2000) nonetheless observed that male stutterers tend to show a greater reduction of speech rate than females under DAF. This reduction, which resulted from an increased duration of individual syllables, was not necessarily perceived, however, as an improvement in fluency. 
Age

Analogous to the finding in non-stutterers that younger individuals are more susceptible to DAF than older individuals (MacKay, 1968; Siegel et al., 1980), Burke (1975), reported more benefit in younger children ( 7 to $12 \mathrm{y}$ ) who stutter than in older children (13 to $18 \mathrm{y}$ ). He also reported, though, that there may be an interaction with stuttering severity and delay time. The positive effect of DAF does not totally wane off with age and several studies reported positive effects in adults as well (see for instance Stuart et al., 1997; Kalinowski et al. 1996; Van Borsel et al., 2002). With regard to the use of DAF in children, Perkins et al. (1974) still remarked that children are often so annoyed by it that they are unwilling to cooperate.

Severity

As far as severity of stuttering is concerned, the general tendency seems to be that there is a significant effect in severe stutterers and no significant improvement in mild stutterers (Soderberg, 1959; Lotzmann, 1961, Naylor, 1953, Nessel, 1958, Ham \& Steer, 1967, Burke, 1975; Sparks et al., 2002). It has even been suggested that less severe stutterers perform much like normal speakers and have difficulty being fluent (Van Riper, 1971). One may wonder then, if perhaps there exists a kind of floor effect and what the critical severity level, for instance in terms of SSI score (Riley, 1994), might be.

\section{Dysfluency pattern}

Systematic research of the impact of the dysfluency pattern exhibited on the effect of DAF is still lacking. Personal clinical observation suggests at any rate that DAF may be less effective in individuals in whom blocks constitute the majority of their fluency failures than in individuals demonstrating predominantly repetitions and prolongations. This is not quite unexpected. For feedback to be changed by a DAF device, there first must be a speech signal, which by definition is lacking in blocks.

\section{Origin of stuttering}

So far DAF has been used most frequently in individuals with developmental stuttering and only occasionally in cases of stuttering of later-onset. Positive effects in individuals with neurogenic stuttering were reported by Downie et al. (1981) in two patients with Parkinsonism, and by Marshall \& Starch (1984) and Marshall \& Neuburger (1987) in respectively 1 and 3 participants who developed stuttering after head inury. Balasubramanian et al. (2003), on the other hand, observed no effect of 50 ms DAF in a 57-year-old male with acquired stuttering following an ischemic lesion in the right frontal lobe and the pons.

\section{Biological subtype}

A recent study by Foundas et al. (2004) suggested that within the population of development stutterers there may be two biological subgroups with different susceptibility to DAF. They found DAF to be more effective in a group of individuals with an atypical planum temporale asymmetry (i.e. right planum temporale larger than left planum temporale) than in a group of individuals with a typical planum temporale asymmetry (left planum temporale larger than right planum temporale). It should be noted, however, that the group with the atypical planar asymmetry was also the group that exhibited greater dysfluency at baseline. As such, it is not clear if the difference in benefit was really caused by the asymmetry of the auditory association cortex or rather by the difference in stuttering severity.

\section{Factors outside the client}

In addition to factors inherent to the client, there are also a number of factors outside the client that should be considered when using DAF. They include delay time, intensity, manner of delivery, speech mode, and speech situation.

\section{Delay time}

All of the currently available DAF devices allow different delay times. With the Kay Elemetrics Facilitator 3500, for instance, delay times from 10 to $500 \mathrm{~ms}$ in $10 \mathrm{~ms}$ increments can be chosen. One of the versions of the Casa Futura SchoolDAF has 16 time delays between 13 and $213 \mathrm{~ms}$. The Belgian device DEFSTUT allows delay times from 0 to 200 $\mathrm{ms}$ in $1 \mathrm{~ms}$ increments. In non-stutterers it has been shown that some delay times are more disruptive than others and that the delay for maximum interference varies with age: the older a subject, the shorter the delay producing maximal interference (MacKay, 1968). From the literature in stuttering it is also quite clear that amelioration 
can be obtained at various auditory feedback delays. From a clinical point of view, the question at stake is whether there exists an optimum delay time?

Kalinowski et al. (1996) defined the optimum delay as "the shortest delay which produces the maximum reduction in stuttering frequency". Delay times used appear to vary from study to study. In the majority of studies a fixed limited number of delay times was tested, less often participants were free to choose the delay time. Studies also vary with respect to how the 'optimum' delay was determined. In some studies the optimum was based on objective measures of dysfluencies, in others it was based on subjective judgments of the participants. Results of some of the major studies that investigated various delay times are summarized in table 1 . In addition, a few authors suggested optimum delay times based on clinical experience Thus Ryan (2004) suggested a delay time of $150 \mathrm{~ms}$, Skotko (2004) a delay time between 58 and $75 \mathrm{~ms}$.

In interpreting the results from the studies included in Table 1 , some caution is necessary. One should take into account that the optimum delay times mentioned are in fact group results that do not necessarily apply in every individual client. Moreover, there is some indication that the optimum delay time may vary according to age, stuttering severity, and therapy history. With regard to age, similar delay times resulted in a greater benefit in younger children than older children in the study by Burke (1975). Similarly, delay times that yielded a significant effect in severe stutterers often showed no significant improvement in mild stutterers (Soderberg, 1959; Lotzmann, 1961; Naylor, 1953; Nessel 1958; Ham \& Steer, 1967; Burke, 1975; Sparks et al., 2002). With respect to therapy history Ryan (2004) observed that individuals, who received intensive treatment in the past that relied heavily on speaking rate reduction, were unable to 'find' adequate control over disfluent moments unless the delay was over $70 \mathrm{~ms}$. The majority of this clients who tried using a delay setting as short as $58 \mathrm{~ms}$ during the initial periods, ultimately requested a DAF increase at least for a while.

Analogous to the question if there is an optimum delay time, one may also ask if there exists a maximum delay time, i.e. the delay time in which DAF ceases to operate and the amount of stutterings under DAF start to outnumber the amount of stutterings under non-altered feedback. According to Soderberg (1969) the maximum delay time, also called the negative Lee-effect, varies with stuttering severity. In milder cases a negative Lee-effect would occur with delay times of 100 and $200 \mathrm{~ms}$, in severe cases with delay times of 200 and $300 \mathrm{~ms}$.

\section{Intensity}

Apart from allowing different delay times the currently available DAF devices also allow to feedback the speech signal at different levels of intensity. According to Butler \& Galloway (1957) the greatest effect of DAF (i.e. most disruptive) in nonstutterers is observed when feedback is loud enough to mask bone conduction with $50 \mathrm{~dB}$. As far as we could ascertain there is only one study that investigated the effect of different intensity levels in stuttering individuals. Using intensity levels of $65,75,85 \mathrm{~dB}$ in nine indiviudals during a reading task Gibney (1973) found that lower intensity levels gave greater facilitation. Overall, studies of DAF in stuttering individuals are far from clear with respect to the intensity level used. Sometimes the intensity level is simply not mentioned (Adamczyk, 1959; Novak, 1978). Sometimes the most comfortable listening level for the participant (Zimmerman et al. 1990, Van Borsel et al. 2003) was used. Still other studies used "a speech level output to the subject's ears that is consistent with auditory self-monitoring during their normal conversation" (85dB SPL) (Kalinowski et al., 1996). As the latter reference suggest, one should indeed make a distinction between signal input level to the microphone and speech output level to the subjects' ears when discussing intensity in the use of DAF. Unfortunately, the manuals of some of the DAF devices are far from specific either on this issue. The Casa Futura SchoolDAF has 10 volume levels and DEFSTUT has 30 volume levels but in neither case there is any specification of the intensity at each possible level. The manual of the Kay Elemetrics Facilitator, on the other hand, is quite specific: the device has an amplitude range of speech output (at headphones) from 70 to $90 \mathrm{dBSPL}$.

\section{Manner of delivery}

With respect to manner of delivery Stuart et al. (1997) found binaural DAF (50-ms delay) to more effective than monaural DAF in a group of eleven participants during reading aloud. Binaural presentation of the feedback signal reduced stuttering on average by $70 \%$, monaural presentation by $60 \%$. No significant differences were found, however, between right and left monaural DAF. 
Speech mode

Studies investigating the effect of DAF in individuals who stutter have done so in different speech modes: reading aloud, picture description, repeating words or sentences, spontaneous speech, and conversation. The available results do as yet not yield a clear picture of the differential effect of DAF in various speech modes. Soderberg (1959) investigated oral reading and spontaneous speech and found a significant reduction of frequency and duration of stuttering in both conditions. Using Picture description and repeating short sentences Burke (1975) reported a reduction of stuttering under DAF in the former condition and an increase in the latter. In the study by Van Borsel et al. (2003) participants stuttered somewhat more in conversation under DAF than during oral reading, picture description, and repeating words and sentence. It should be remarked that all data today are based on assessment in laboratory situations. Objective data on the effect of DAF in different real everyday speaking situations are still lacking.

TABLE 1. Overview of studies that investigated various delay times

\begin{tabular}{cc}
\hline Study & Optimum delay (ms) in italic \\
\hline Soderberg (1969) & $60-100-140-220$ \\
Lotzmann (1961) & $50-100-150-200-250-300$ \\
Novak (1978) & $55-110-165-220$ \\
Kalinowski et al. (1996) & $25-50-75$ \\
Van Borsel et al. (2003) & $93-147 ;>93$ \\
\hline
\end{tabular}

\section{Possible side-effects}

When applying delayed auditory feedback, one should also reckon with a number of possible sideeffects. These include a reduction in speech rate, an increase of speaking fundamental frequency and vocal intensity, lengthening of vowels, and a possible effect on speech naturalness.

According to Andrade et al (2003, p.81): "... speech rate is an important index when analyzing the effectiveness of treatment, since one of the goals of speech therapy is to provide for the patient the ability to present the same speech pattern as that of individuals with no communication deficits, i.e. such that the patient's speech does not sound different from that of fluent speakers". Britto
Pereira et al (2003) found that the duration of consonants of stutterers when fluent is smaller than that of fluent speakers, indicating that when they are fluent, stutterers speak faster than fluent speakers. This might reflect a compensatory mechanism in the speech rate, trying to keep the balance of the prosodic structure.

Generally speaking, DAF slows the speech rate and the higher the delay time the more the speech rate is reduced. A number of authors have also suggested that it is precisely the reduction in speech rate that brings about fluency under DAF (Wingate, 1976; Perkins, 1979; Costello-Ingham, 1993). Studies by Kalinowski et al. (1993, 1996) and McLeod et al. (1995), however, have shown that a slow speech rate is not really necessary for fluency enhancement under DAF. They observed decreases in stuttering frequency at both normal and fast rates of speech with a 50ms delay.

It has also been observed that speaking under DAF may lead to an increase of fundamental frequency (Soderberg, 1959; Lechner, 1970), at least at delay times of $140 \mathrm{~ms}$, and to an increase of vocal intensity (Howell, 1990), similar to what has been observed in non-stutterers under DAF (Lee, 1951; Black, 1951; Atkinson, 1953; Fairbanks, 1955; Chase et al. 1961b). Perhaps these changes represent a kind of Lombard effect. In addition, Howell (2004) and Howell et al. (1988) reported that people who stutter tend to elongate the vowels under DAF, an effect that would be ameliorated by using short delay times.

To what extent possible changes like that of speech rate, fundamental frequency, vocal intensity, and vowel duration affect speech naturalness, is as yet unclear. There are only a few studies on speech naturalness under DAF yielding moreover conflicting results. While Martin et al. (1984) found no difference in naturalness in people who stutter under non-altered feedback compared to DAF, Stuart and Kalinowski (2004) and Stuart et al. (2006) found speech significantly more natural sounding with the device than without the device. Perhaps this divergent findings result from the use of a different delay time $(250 \mathrm{~ms}$ in the study of Martin et al.1984 versus 50ms and 60ms in the study of Stuart and Kalinowski, 2004 and Stuart et al. 2006 respectively) and maybe also the combination with frequency altered feedback $(+500 \mathrm{~Hz}$ in the study of Stuart et al. 2006). Natke (2000) suggested that the critical delay time with respect to naturalness lies at $100 \mathrm{~ms}$, above which speech would start to sound unnatural. 


\section{Others}

Finally, we must mention yet three other aspects to reckon with when considering the use of DAF in an individual client: cosmetics, finances, and the long-term effect. The currently available DAF devices differ significantly from one another as to size and conspicuousness and what is cosmetically acceptable for one client is probably not for another. Conspicuousness may be a factor that prevents a client to make use of the device in spite of a positive effect on speech fluency (Van Borsel et al., 2003). In this respect the SpeechEasy devices developed by Janus Dev. Group, the smallest of which fits completely in the ear canal, are by far the most attractive types but they are also the most expensive ones.

Purchasing a DAF device always implies a substantial financial investment anyhow, with prices ranging from 995 US\$ (the casa futura school DAF) to 4900 US\$ (the completely in the canal SpeechEasy device), depending also on additional possibilities and options (such as for instance other types of altered feedback, automatic voice activation, noise-canceling,...). It should be recognized that the devices normally come with a trial period and warranty. The devices from Casa Futura for instance may be returned within 60 days for a $100 \%$ refund when sold to, bought from, or approved by a speech-language pathologist and returned within 30 days for a $90 \%$ refund when bought by consumers directly from Casa Futura Technologies. Comparable conditions are applied by the Janus Dev. Group and Laytec for the SpeechEasy devices and the DEFSTUT respectively.

Although a trial period is certainly an apt procedure to find out if a given client may possibly benefit from the use of a DAF device, satisfaction will ultimately depend on the long term effect. The available data suggest that an immediate reduction of stuttering when speaking under DAF does not always persists over time but it seems as yet difficult to predict in which clients the effect of DAF will or will not wear off. Nor is clear which factors are involved. Adamczyck (1959) reported a great improvement in speaking in 13 cases and a slight improvement in 2 cases using DAF for 2 to 3 months. In the nine participants in the study by Van Borsel et al. (2003) repeated exposure to DAF continued to promote fluency over a 3 month period but there was no evidence that length of exposure and fluency enhancement were in a linear relationship. Using DAF in combination with FAF (frequency altered feedback) in nine people who stutter, Stuart et al. (2006) found that the proportions of stuttering events were significantly reduced at initial fitting and remained so 12 months post follow-up. A number of studies in individuals with dysfluencies of neurogenic origin reported mixed results. A 32year-old man with a four year history of acquired stuttering studied by Marshall and Starch (1984) continued to emit less than three stuttered syllables per minute at follow-up sessions at 2, 7, 9, 2128 and 101 days after completion of the formal treatment program with DAF. Marshall and Neuburger (1987), however, observed a return to baseline stuttering levels during the maintenance phase and reoccurrence of stuttering at follow up (3 months) in two of three cases acquired stuttering following head injury. And of two patients with Parkinsonism reported by Downie (1981) the first maintained useful benefit for about one year but by then he appeared to become habituated and the apparatus was no longer effective. The second patient found the apparatus still extremely helpful after two years use.

\section{Conclusions}

It cannot be denied that DAF may have a positive effect on speech fluency in a number of stutterers. An overview of the relevant literature shows, however, that most likely multiple factors play a role and with the currently available data it is very hard to predict whether an individual will or will not benefit from the use of DAF. Overall, the evidence for the influence of the different factors is still meager. Moreover, some studies present data of a quality that can hardly be considered "evidence". The present review raised more questions than answers which can only be answered by future research. 


\section{References}

ADAMCZYK, B. Use of instruments for the production of artificial feedback in the treatment of stuttering. Folia Phoniatr., Basel, v. 11, p. 216-218, 1959.

ANDRADE, C. R. F. Prevalência das desordens idiopáticas da fala e da linguagem em crianças de 1 a 11 anos de idade. $R$. Saúde Públ., São Paulo, v. 31, n. 5, p. 495-501, out. 1997. ANDRADE, C. R. F. Programa fonoaudiológico de promoção da fluência em adultos gagos: tratamento e manutenção. In: LIMONGI, S. C. O. Fonoaudiologia: informação para a formação - procedimentos terapêuticos em linguagem. Rio de Janeiro: Guanabara Koogan, 2003. p. 27-53

ANDRADE, C. R. F.; CERVONE, L. M.; SASSI, F. C. Relationship between the stuttering severity index and the speech rate. São Paulo Med. J., São Paulo, v. 121, n. 2, p. $81-84,2003$.

ANDRADE, C. R. F.; SASSI, F. C. A study about electromyography: rest, maximum and minimum labial tension in fluent speakers. Pro-Fono R. Atual. Cient., Barueri (SP), v. 15, n. 2, p. 111-116, maio-ago. 2003

ANDRADE, C. R. F.; SEPULCRE, A. S.; ROMANO, M. V. R.; JUSTE, F.; SASSI, F. C. Percepção de pais de crianças gagas e fluentes sobre as características de temperamento de seus filhos. R. Soc. Bra. Fonoaudiol., São Paulo, v. 9 n. 4, p. 205-211, out.-dez. 2004.

ATKINSON, C. J. Adaptation to delayed sidetone. J. Speech Hear. Dis., v. 18, n. 4, p. 386-391, dec. 1953.

BACHRACH, D. L. Sex differences in reactions to delayed auditory feedback. Percept. Motor Skills, v. 19, p. 81-82, ago. 1964.

BALASUBRAMANIAN, V.; MAX, L.; VAN-BORSEL, J. O.; RAYCA, K.; RICHARDSON, D. Acquired stuttering following right frontal and bilateral pontine lesion: a case study. Brain Cognit., v. 53, n. 2, p. 185-189, nov. 2003.

BLACK, J. W. The effect of delayed side-tone upon vocal rate and intensity. J. Speech Hear. Dis., v. 16, n. 1, p. 5660, mar. 1951.

BLOODSTEIN, O. A handbook on stuttering. London: Chapman \& Hall, 1995.

BOHR, J. W. F. The effects of electronic and external control methods on stuttering: a review of some research. J. South African Logopedic Soc., v. 10, p. 4-13, 1963.

BURKE, B. D. Variables affecting stutterer's initial reactions to delayed auditory feedback. J. Commun. Dis., v. 8 , n. 2, p. 141-155, jun. 1975 .

BUTLER, R. A.; GALLOWAY, F. T. Factorial analysis of the delayed speech feedback phenomenon. J. Acoustic. Soc. Am., v. 29, n. 5, p. 632-635, may 1957.

PEREIRA, M. M. B.; FERRANTE, C.; COHEN, C.; CARVAlHO, G. G. T. Análise da duração de consoantes na fala fluente de gagos. R. Soc. Bras. Fonoaudiol., São Paulo, n. 2, dez. 2003.

CHASE, R. A.; SUTTON, S.; FIRST, D.; ZUBIN, J. A developmental study of changes in behavior under delayed auditory feedback. J. Genetic Psychol., v. 99, p. 101-112, sept. $1961 \mathrm{a}$.
CHASE, R. A.; SUTTON, S.; RAPIN, I. Sensory feedback influences on motor performance. J. Auditory Res., v. 1, p. 212-223, $1961 \mathrm{~b}$.

COSTELLO-INGHAM, J. Current status of stuttering and behavior modification: I - recent trends in the application of behavior modification in children and adults. J. Fluency Dis., v. 18, n. 1, p. 27-55, 1993.

DOWNIE, A. W.; LOW, J. M.; LINDSAY, D. D. Speech disorders in Parkinsonism: use of delayed auditory feedback in selected cases. J. Neurol. Neurosurg. Psychiat., v. 44, n. 9, p. $852-853$, sept. 1981 .

FAIRBANKS, G. The effects of delayed sidetone upon vocal rate and intensity. J. Speech Hear. Dis., v. 20, n. 4, p. 333-346, dec. 1955 .

FOUNDAS, A. L.; BOLLICH, A. M.; FELDMAN, J.; COREY, D. M.; HURLEY, M.; LEMEN, L. C.; HEILMAN, K. M. Aberrant auditory processing and atypical planum temporale in developmental stuttering. Neurol., v. 63, n. 9, p. 1640-1646, nov. 2004.

FUKAWA, T.; YOSHIOKA, H.; OZAWA, E.; YOSHIDA, S. Difference in syusceptibility to delayed auditory feedback between stutterers and nonstutterers. J. Speech Hear. Res., v. 31, n. 3, p. 475-479, sept. 1988.

GIBNEY, N. Delayed auditory feedback: changes in the volume intensity and the delay interval as variables affecting the fluency of stutterer's speech. British $J$. Psychol., v. 64, n. 1, p. 55-63, feb. 1973.

GREGORY, H. Stuttering: differential evaluation and therapy. Texas: Pro Ed Austin, 1986.

GROSSER, J.; NATKE, U.; LANGEFELD, S.; KALVERAM, K. T. Reduction in stuttering by delayed and frequency shifeted auditory feedback: effect of adaptation and sex differences. J. Fluency Dis., Autumn, v. 25, n. 3, p. 252-252, 2000.

HAM, R. E.; STEER, M. D. Certain effects of alterations in auditory feedback. Folia Phoniat., Basel, v. 19, n. 1, p. 53-62, 1967.

HOWELL, P. Changes in voice level caused by several forms of altered feedback in fluent speakers and stutterers. Lang. Speech, v. 33, n. 4, p. 325-338, oct.-dec. 1990.

HOWELL, P. Effects of delayed auditory feedback and frequency shifted feedback on speech control and some potentials for future development of prostehtic aids for stammering. Stammering Res., v. 1, n. 1, p. 31-46, abr. 2004. Disponível em: <http:// w w w. s t a m r e s.p s y c ho 1. u c 1. a c . u k / stammering.issue1.pubd.htm>. Acesso em: 03 jul. 2007.

HOWELL, P.; WINGFIELD, T.; JOHNSON, M. Characteristics of the speech of stutterers during normal and altered auditory feedback. In: AINSWORTH, W. A.; HOLMES, J. N. Proceedings speech. 5. ed. Edinburgh: Institute of Acoustics, 1988. p. 1069-1076. v. 3.

KALINOWSKI, J.; ARMSON, J.; ROLANDMIESZKOWSKI, M.; STUART, A.; GRACCO, V. L. Effects of alterations in auditory feedback and speech rate on stuttering frequency. Lang. Speech, v. 36, n. 9, p. 1-16, jan.-mar. 1993. 
KALINOWSKI, J.; STUART, A.; SARK, S.; ARMSON, J. Stuttering amelioration at various auditory feedback delays and speech rates. Europ. J. Dis. Commun., v. 31, n. 3, p. 259-269, 1996.

LECHNER, B. K. The effects of delayed auditory feedback and masking on the fundamental frequency of stutterers and non-stutterers. J. Speech Hear. Res., v. 33, n. 2, p. 343-353, jun. 1970.

LEE, B. S. Some Effects of side-tone delay. J. Acoustic. Soc. Am., v. 22, n. 5, p. 639-640, sept. 1950.

LEE, B. Artificial stutter. J. Speech Hear. Dis., v. 16, n. 1, p. 53-55, mar. 1951.

LOTZMANN, G. On the use of varied delay times in stammerers. Folia Phoniatr., Basel, v. 13, p. 276-310, 1961.

MACKAY, D. Metamorphosis of a critical interval: agelinked changes in the delay of auditory feedback that produces maximum disruption of speech. J. Acoustic. Soc. Am., v. 43, n. 4, p. 1-21, abr. 1968.

MACLEOD, J.; KALINOWSKI, J.; START, A.; ARMSON, J. Effect of single and combined auditory feedback on stuttering frequency at two speech rates. J. Commun. Dis., v. 28, n. 3, p. 217-228, sept. 1995.

MAHAFFEY, R.; STROMSTRA, C. The effects of auditory feedback as a function of frequency, intensity, time and sex. Therap. Vocis Loquella, v. 2, p. 233-235, 1965.

MARSHALL, R. C.; STARCH, S. A. Behavioral treatment of acquired stuttering. Australian J. Hum. Commun. Dis., v. 12, p. $87-92,1984$.

MARSHALL, R. C.; NEUBURGER, S. I. Effects of delayed auditory feedback on acquired stuttering following head injury. J. Fluency Dis., v. 12, n. 5, p. 355-365, oct. 1987.

MARTIN, R. R.; HAROLDSON, S. K.; TRIDEN, K. A. Stuttering and speech naturalness: some additional data. J. Speech Hear. Dis., v. 49, n. 1, p. 53-58, feb. 1984

NATKE, U. Stotterreduktion bei frequenzverschobener und verzögerter auditiver Rückmeldung. Folia Phoniatr. Logopaed., Basel, v. 52, n. 4, p. 151-159, jul.-aug. 2000.

NAYLOR, R. V. A comparative study of methods of estimating the severity of stuttering. J. Speech Hear. Dis., v. 18, n. 1 , p. $30-37$, mar. 1953

NESSEL, E. Die Verzögerte Sprachrückkopplung (Lee effect) bei Stottern. Folia Phoniatr., Basel, v. 10, p. 87 89, 1958.

NOVAK, A. The influence of delayed auditory feedback in stutterers. Folia Phoniatr., Basel, v. 30, n. 4, p. 278$285,1978$.

PERKINS, W.; RUDAS, J.; JOHNSON, L.; MICHAEL, W. B.; CURLEE, R. F. Replacement of stuttering with normal speech: III - clinical effectiveness. J. Speech Hear. Dis., v. 39, p. 416-428, 1974.

PERKINS, W. H. From psychoanalysis to discoordination. In: GREGORY, H. H. Controversies about stuttering therapy. 5. ed. Baltimore: University park Press, 1979. p. 97-127.

RILEY, G. D. A. Stuttering Severity Instrument for children and adults. Austin: Pro-Ed, 1994.
RYAN, B. Programmed stuttering therapy for children and adults using ARAI. Stammering Res., v. 1, n. 1, p. 6262, apr. 2004. Disponível em: <http:// w w w. s t a m r e s.p s y c ho 1. u c l. a c.u k/ stammering.issue1.pubd.htm>. Acesso em: 03 jul. 2007.

SASSI, F. C. Eletromiografia de superfície e promoção de fluência: estudos sobre a efetividade do tratamento. 2003. 180 f. Tese (Doutorado em Ciências) - Faculdade de Medicina, Universidade de São Paulo, São Paulo.

SASSI, F. C.; ANDRADE, C. R. F. Eletromiografia de superfície e o tratamento da gagueira: uma perspectiva neuromotora. R. Soc. Bras. Fonoaudiol., São Paulo, v. 9 , n. 1, p. 55-60, jan.-mar. 2004.

SCHIEFER, A. M. Abordagem psicolingüística da fluência. In: FERREIRA, L. P.; BEFI-LOPES, D. M.; LIMONGI, S. C. O. Tratado de fonoaudiologia. São Paulo: Roca, 2004. p. 1035-1039.

SIEGEL, G. M.; FEHST, C. A.; GARBER, S. R.; PICK, H. L. Delayed auditory feedback with children. J. Speech Hear. Res., v. 23, n. 4, p. 802-813, dec. 1980.

SKOTKO, J. Experience of a speech pathologist providing clients with the SpeechEasy ${ }^{\mathrm{TM}}$ device. Stammering Res., v. 1, n. 1, p. 63-65, apr. 2004. Disponível em: <http:// w w w . s t a m re s.p s y c h o 1. u c 1. a c . u k / stammering.issue1.pubd.htm>. Acesso em: 03 jul. 2007.

SODERBERG, G. A. A study of the effects of delayed auditory side-tone on four aspects of stutterer's speech during oral reading and spontaneous speech. 1959. Disseration (Doctoral) - University Microfilms, The Ohio State University, Ohio.

SODERBERG, G. A. Delayed auditory feedback and the speech of stutterers. J. Speech Hear. Dis., v. 4, n. 1, p. 2029, feb. 1969.

SPARKS, G.; GRANT, D. E.; MILLAY, K.; WALKERBATSON, D.; HYNAN, L. S. The effect of speech rate on stuttering frequency during delayed auditory feedback. $J$. Fluency Dis., v. 27, n. 3, p. 187-201, sept. 2002.

ST LOUIS, K. O.; ANDRADE, C. R. F.; DOBRINKA, G.; TROUDT, F. O. Experiência e relato pessoal sobre pesquisa de cooperação internacional - Brasil, Bulgária e Turquia que avalia as atitudes em relação à gagueira. Pro-Fono $R$. Atual. Cient., Barueri (SP), v. 17, n. 3, p. 413-416, set.dez. 2005.

STUART, A.; KALINOWSKI, J.; RASTATTER, M. P. Effect of monoaural and binaural altered auditory feedback on stuttering frequency. J. Acoustic. Soc. Am., v. 101, n. 6, p. 3806-3809, jun. 1997.

STUART, A.; KALINOWSKI, J. The perception of speech naturalness of post-therapeutic and altered auditory feedback speech of adults with mild and sever stuttering. Folia Phoniatr. Logopaedica, Basel, v. 56, n. 6, p. 347 357, nov.-dec. 2004.

STUART, A.; KALINOWSKI, J.; SALTUKLAROGLU, T.; GUNTUPALLI, V. K. Investigations of the impact of altered auditory feedback in the ear devices on the speech of people who stutter: one year follow up. Disabil. Rehabilit., v. 28, n. 12, p. 757-765, jun. 2006.

SPARKS, G.; GRANT, D. E.; MILLAY, K.; WALKERBATSON, D.; HYNAN, L. S. The effect of fast speech rate on stuttering frequency during delayed auditory feedback. J. Fluency Dis., v. 27, p. 187-201, 2002. 
TIMMONS, B. A. Sex as a factor influencing sensitivity to delayed auditory feedback. Percept. Motor Skills, v. 32, n. 3, p. 824-826, jun. 1971.

VAN BORSEL, J.; REUNES, G.; VAN-DEN-BERGH, N. Delayed auditory feedback in stuttering. Clients as consumers. Int. J. Lang. Commun. Dis., v. 38, n. 2, p. 119-129, abr.-jun. 2003.

VAN RIPER, C. The nature of stuttering. Englewood Cliffs, NJ: Prentice Hall, 1971.

VAN RIPER, C. The treatment of stuttering. Englewood Cliffs, NJ: Prentice Hall, 1973.

WARD, D. Stuttering and cluttering: frameworks for understanding and treatment. New York: Psychology Press, 2006.
WINGATE, M. E. Stuttering: theory and treatment. New York: Irvington, 1976.

WORLD HEALTH ORGANIZATION. Manual of international statistical classification of diseases, injuries, and causes of death. Geneva (Switzerland): World Health Organization, 1977. v. 1

ZERNERI, L. Attempts to use delayed speech feedback in stuttering therapy. J. Français d'oto-rhino-laryngol. chirurg. maxillo-facial, v. 15, n. 4, p. 415-418, jul.-aug. 1966.

ZIMMERMAN, S.; KALINOWSKI, J.; STUART, A.; RASTATTER, M. Effect of altered auditory feedback on people who stutter during scripted telephone conversations. J. Speech Lang. Hear. Res., v. 40, n. 5, p. 1130-1134, oct. 1997. 